\title{
14
}

\section{How effective are China's capital controls?}

\author{
Guonan Ma and Robert N. McCauley
}

Competing interpretations of the interaction of domestic monetary policy and the foreign exchange rate in China often arise from different assumptions regarding the effectiveness of capital controls. At one end of the spectrum is the view that capital controls merely alter the form of capital flows without altering their magnitude. In this view, the heavily managed renminbi exchange rate implies that China imports its monetary policy and lacks control over local short-term interest rates. At the other end is the view that capital controls are still binding enough to allow the Chinese government to set short-term interest rates, despite the limited flexibility of the exchange rate. The contrasts between these views sharpen in the context of growing cross-border flows under the current and capital accounts in the past 10 years as well as the accelerated foreign reserve accumulation since 2005.

Different views on the status quo also inform the interpretation of outcomes for future liberalisation of capital flows. Again, at one extreme, this would unevenly lower transaction costs and thereby alter the mix of cross-border capital flows, but without necessarily affecting their total volume. In this interpretation, capital account liberalisation might be of interest to specialists in international finance, but not to those who follow the Chinese macroeconomy. At the other extreme, capital account liberalisation would influence the scale and composition of capital flows and ultimately force a choice between exchange rate management and an independent monetary policy. 
This chapter examines price evidence to determine how effective China's capital controls have been in the past and how effective they remain. We focus on the analysis of price evidence because it provides the most telling evidence on the question (for a discussion of the flow evidence, see Ma and McCauley forthcoming). Our basic conclusion is that sustained interest rate differentials mean that Chinese capital controls have continued to bind. These observed differentials cannot, in our view, be accounted for plausibly by liquidity or credit factors. Even the narrowing of these differentials since the unpegging of the renminbi in July 2005 leaves them at substantial levels. If capital controls still bite, future liberalisation is likely to proceed incrementally in order to accommodate a shifting balance of exchange rate and financial and monetary stability objectives.

We define monetary autonomy narrowly in terms of the government's ability to set short-term domestic interest rates. Such a definition could be appropriate to many industrial countries where monetary policy has confined itself to setting a short-term interest rate. In fact, China's monetary policy employs a wide variety of other instruments, including administrative controls of deposit and minimum lending rates as well as quantitative measures such as reserve requirements, lending quotas, window guidance and restrictions on investment. Such measures could give China's monetary policy room to manoeuvre even if its short-term interest rates were tightly constrained by the exchange rate policy. Thus, a finding that short-term interest rates are not tightly constrained implies a fortiori monetary independence in the broader sense, which is more relevant in the case of China.

\section{Growing cross-border flows in China}

China's capital control regime has two important features. First, capital controls tended to be tighter for cross-border flows thought to be more volatile than for more stable flows. Second, the regulatory regime over time has shifted from one biased against outflows towards one managing two-way cross-border capital flows in a more balanced fashion. Related to the latter is the tendency for policymakers to systemically 'lean against the wind' in the sense that control measures on outflows are strengthened to resist depreciation pressures on the exchange rate and vice versa. While such a discriminatory control regime could complicate any analysis, more stringent control measures over short-term flows to resist prevailing market pressures would highlight short-term interest rates as a useful measure of the efficacy of capital controls.

One factor conditioning the efficacy of capital controls is the size of external flows. Despite continued capital controls, the past two decades have witnessed 
a rapid rise in China's cross-border flows on the current and capital accounts. As a share of gross domestic product (GDP), China's gross cross-border flows more than quintupled to more than 120 per cent in 2005, from less than 20 per cent in 1982 (Figure 14.1), with a noticeable acceleration in the 1990s. Also, notwithstanding the remarkable expansion of the gross current account flows, China's capital account flows have been gaining relative importance. In 2005, gross capital account flows represented one-third of China's total gross crossborder flows, compared with just 13 per cent in 1982 and 25 per cent in 1990. ${ }^{2}$

The backdrop of growing cross-border flows suggests that the Chinese economy has become increasingly open and integrated into the global economy and is thus more prone to influences from global markets than before. In particular, larger external flows point to more opportunities to avoid and evade capital controls. This in turn raises questions about the efficacy of capital controls, with implications for monetary autonomy, financial stability and future capital account liberalisation.

Figure 14.1 China's gross cross-border flows, ${ }^{a}$ 1982, 1990 and 2005 (per cent of GDP)

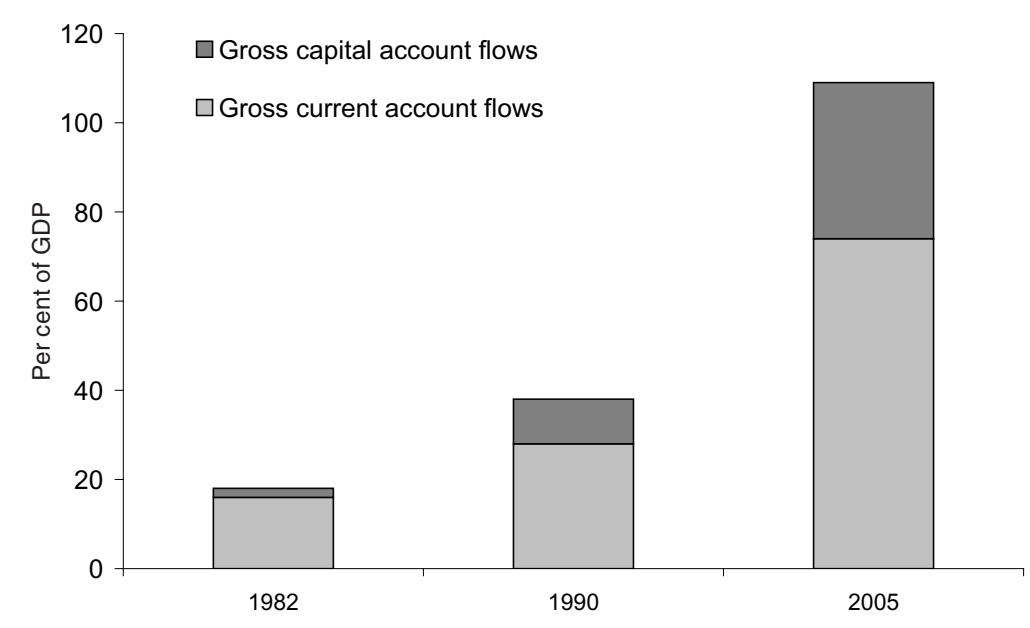

\footnotetext{
a Defined as the sum of debit and credit flows on China's balance of payments, excluding net errors and omissions.
}

Source: CEIC Data Company. 
Growing trade and financial openness, however, does not support an immediate conclusion about the efficacy of capital controls. In particular, even large and highly responsive cross-border flows could limit without gutting capital controls, just as small and stable flows need not imply effective controls. A more direct and stringent test of capital control effectiveness is whether substantial cross-border arbitrage opportunities persist for a considerable period. Such a test-based not on flows but on onshore and offshore prices-can also indicate how the effectiveness has varied over time. When price and flow measures are consistent with each other, one can arrive at an easy conclusion regarding capital mobility; but when they point in different directions, price evidence should be given more weight. In a departure from the existing literature, we examine only the price measures in gauging the capital mobility.

\section{Price test of capital mobility: onshore and offshore renminbi yields}

The combination of onshore renminbi interest rates, offshore US dollar rates and non-deliverable forward (NDF) exchange rates is analysed next, to test for capital mobility between China and the offshore financial markets. The null hypothesis is that there are no substantial differences between renminbi interest rates onshore, on the one hand, and those implied by the offshore NDFs in conjunction with US dollar Libor, on the other. ${ }^{3}$ The methodology of estimating such onshore-offshore renminbi yield gaps is based on Ma et al. (2004), as detailed in the Appendix. The idea is that large and persistent onshore-offshore yield gaps suggest significant cross-border market segmentation and thus binding capital controls; but occasional small gaps do not necessarily imply ineffectiveness of capital controls. We interpret the evidence as supporting the alternative hypothesis of there being an economically substantial gap between onshore and offshore renminbi yields. Acceptance of this hypothesis favours the view that capital controls in China have so far remained substantially binding.

\section{Measuring onshore and offshore renminbi yield differentials}

Especially in the case of relatively less-developed money and foreign exchange markets, instruments must be chosen carefully to perform this test. Care must be exercised in the dimensions of maturity, liquidity and credit. Ideally, one wants to compare instruments of identical maturity, enjoying the same liquidity, which are issued by the same private parties, usually banks. An appropriate comparison would be between the yields on large US dollar certificates of deposit in New York versus yields on US dollar deposits posted in London by the top-rated banks that report to the British Bankers Association (BBA). Such 
a comparison often is based on the three-month maturity that is representative of domestic and offshore yields. The banks involved in the comparison are quite similar in their double-A credit standing.

Liquidity considerations. In the case of China, the challenge has in practice come from getting a reasonable match between a representative renminbi money market yield, on the one hand, and the NDF rate, on the other. In particular, the interbank renminbi money market trades with greatest liquidity at very short maturities - overnight to seven days - while the NDF market trades with greatest liquidity at longer tenors of three months to one year.

This chapter improves on the previous estimates of onshore-offshore renminbi yield gaps in the dimension of liquidity (Ma et al. 2004). The latter traded off the above considerations and chose to compare the three-month China interbank offered rate (CHIBOR) yield to the three-month NDF. ${ }^{4}$ This comparison stretched to a relatively long and illiquid maturity in the domestic money market, on one hand, and took a relatively short maturity in the offshore market, on the other. Here, we update these earlier measures as well as complement the earlier analysis with a new comparison based on a different pair of instruments. In particular, we also compare the weekly auction rates for PBC one-year bills available since 2004 with the one-year NDF. This choice compares liquid instruments in both markets, although it introduces possible credit differences between the sovereign bill and the bank NDF or deposit (see below).

Liquidity across the two markets matches well at the one-year tenor. The PBC issued 1.2 trillion renminbi (about US $\$ 150$ billion) of its one-year bills in 2005 out of a total bill issuance of 2.8 trillion renminbi, for an average weekly issuance of about US $\$ 3$ billion equivalent. ${ }^{5}$ From January to March 2006, issuance ranged between 40 and 120 billion renminbi a week. In the NDF market, the one-year maturity is reportedly the most traded maturity (Ma et al. 2004; Debelle et al. 2006).

The less liquid the instruments that are used for arbitrage of onshore and offshore yields, the less telling are observed small yield differences. One can think of an arbitrage tunnel inside of which further arbitrage transactions are not profitable, given bid-ask spreads and any tendency for flows of orders to move the market. The upshot is that a finding that capital controls are ineffective could well be consistent with observed yield gaps of, say, 25 basis points or less.

Credit considerations. With regard to credit, comparing sovereign and bank yields on onshore and offshore instruments, respectively, is problematic in principle, but in practice it does not skew the comparison substantially. Credit default swaps suggest that the credit standing of China attracts an insurance payment of only a handful of basis points more than that of the major 
international banks that form the US dollar Libor panel (see Table A14.2). Since offshore renminbi rates were lower than the onshore $\mathrm{PBC}$ bill yield in the period 2004-06, the mixing of sovereign and bank credit does widen the estimated yield gap for this period, thus favouring the finding that capital controls are effective. But as we will see below, the scale of the estimated yield differences of 100 to 400 basis points dwarfs the five basis point credit difference.

With our earlier comparison of CHIBOR and offshore yields, credit differences tended to reduce the absolute value of the observed yield differentials over much of the sample period. From 1999 to 2001, highly rated banks dealing offshore under international law paid higher (implied) yields than did domestic Chinese banks dealing onshore. Taking into account the credit difference would only have widened the gap.

An example of cross-border arbitrage on renminbi interest rates. Before examining the data, it might be useful to consider a particular example of an arbitrage transaction at the one-year tenor by a multinational firm with a profitable operation in China. Since September 2003, the offshore speculative demand to be long in renminbi has given the treasurer of such a firm a strong incentive to, in effect, hold renminbi onshore and sell them forward offshore (that is, lending renminbi onshore and borrowing them offshore). One way of constructing such a position is for the affiliate in China not to convert renminbi into dollars in order to remit a dividend to its parent outside China. Instead, the funds are retained in renminbi and invested in the Chinese money market. The yield on the one-year deposit is proxied by the PBC bill rate (one can think of a bank taking the funds in trust and investing in the PBC bill). Thus, renminbi funds have been lent onshore.

Simultaneously, the affiliate borrows dollars at one-year Libor, replacing the cash flow of the unpaid dividend from China, and sells renminbi one year forward against US dollars, say, to a hedge fund. This combination of dollar borrowing and forward position amounts to borrowing renminbi offshore and converting the proceeds into dollars, and the rate of interest paid is (by construction) the relatively low NDF-implied renminbi yield. At the year's end, the renminbi invested onshore can be sold for dollars at the then-prevailing spot exchange rate, which is also used to determine any profit or loss on the NDF, leaving the firm with the arbitrage gain between the interest rate in the Chinese money market and the lower offshore yield. Thus, by lagging a current dollar payment-namely, the profit repatriation-the firm has in effect acquired a long renminbi position and locked in a gain by selling it offshore.

One of the useful features of this example is that it shows that arbitrage between the onshore money market and the offshore forward market is 
not limited to banks. Of course, not all foreign firms operating in China are profitable; some have entered joint ventures that constrain such arbitrage and not all would be willing to increase their balance sheet in China. Nevertheless, such corporate opportunities are telling because otherwise a failure to equalise interest rates could be taken to be merely a symptom of the inefficiency of Chinese banks. Instead, the profit opportunities present themselves to global companies, which can be presumed to bring to China efficient treasury operations and indeed the benefit of having operated within and around capital controls in other economies.

\section{Onshore-offshore renminbi yield differentials based on three-month CHIBOR}

Our earlier analysis compared a domestic interest rate-the so-called threemonth $\mathrm{CHIBOR}$ - with the offshore renminbi rate implied by three-month NDFs and dollar Libor. We found economically very significant differences. Figure 14.2 compares the three-month yield gap for the renminbi with Asian peers for the periods 1999-2001 and 2002-04. The absolute value of the gap between renminbi yields onshore and offshore averaged 250-300 basis points in the five years to early 2004. This placed China in the middle of our sample and indeed is very wide compared with the onshore-offshore differential of $50-100$ basis points for the Korean won in the same period, and a gap of 20-30 basis points observed for the Japanese yen before capital controls were lifted in the early 1980s (Otani and Tiwari 1981). The narrowing of the differentials in 2002-04 was in fact less evident in the case of China than for most of the other Asian currencies.

An updated estimate of the yield gap for 1999-2006 reveals an even bigger average gap of 310 basis points in absolute value and also suggests several distinct phases of market conditions (Figure 14.3). In general, if controls bind, one would expect offshore rates to be above onshore rates when market participants are positioning for renminbi weakness and the net direction of flows of funds is outward. Conversely, offshore rates would fall below onshore rates when positioning favours renminbi strength and funds are seeking to enter China.

In the period from the East Asian financial crisis through until early 2001, the weight of offshore positioning was in the direction of a weakening renminbi, resulting in higher yields offshore. Then followed a period of smaller differences during 2001-02, which saw offshore rates below those onshore, but with a gap of less than 150 basis points. This period featured more balanced positioning on the renminbi. With the intensification of public pressure from 


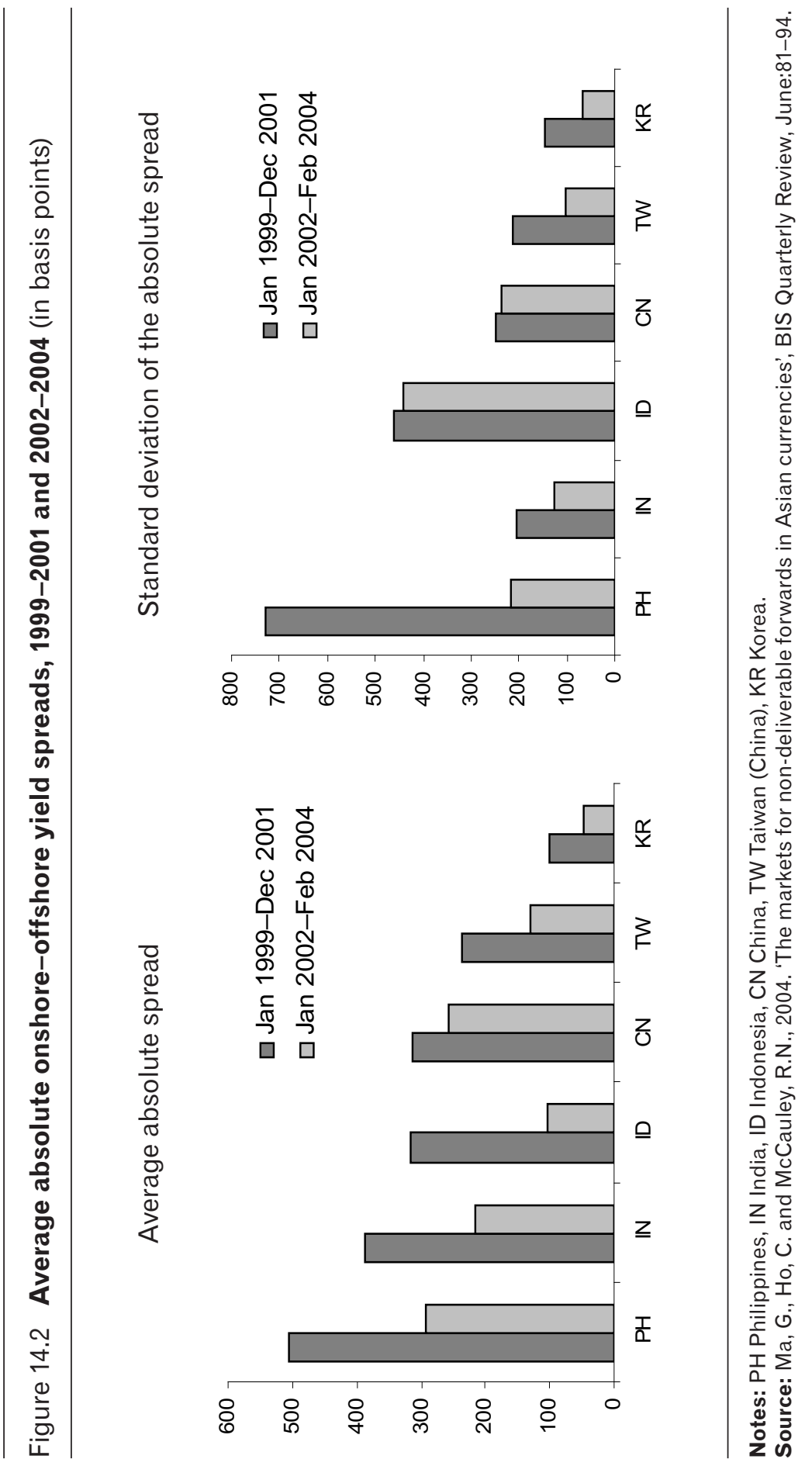


trading partners on China's exchange rate policy in September 2003, however, offshore yields dropped substantially below their onshore counterparts. The weight of offshore positioning was in the direction of a strengthening renminbi. As Chinese companies converted dollar holdings or borrowings into renminbi, reserve growth accelerated, far exceeding the pace that could be explained by the current account surplus and direct investment inflows. The average yield gap widened to more than 360 basis points from January 2003 to April 2006. The gap reached a peak of 800 basis points in mid 2005, when the implied offshore yield fell well below zero. ${ }^{6}$ Since the July 2005 policy change, however, the yield gap has narrowed markedly - to less than 200 basis points.

The principal message based on our previous and more updated estimates of three-month tenor of the CHIBOR and renminbi NDF is that the onshoreoffshore gap in the renminbi yields has been persistently substantial in absolute terms and its sign has been consistent with prevailing market pressures. In other words, hitherto, China's capital controls have prevented sufficient crossborder arbitrage to equalise onshore and offshore short-term yields.

Figure 14.3 The onshore less offshore renminbi yields, based on threemonth CHIBOR, 1998-2006 (in basis points)

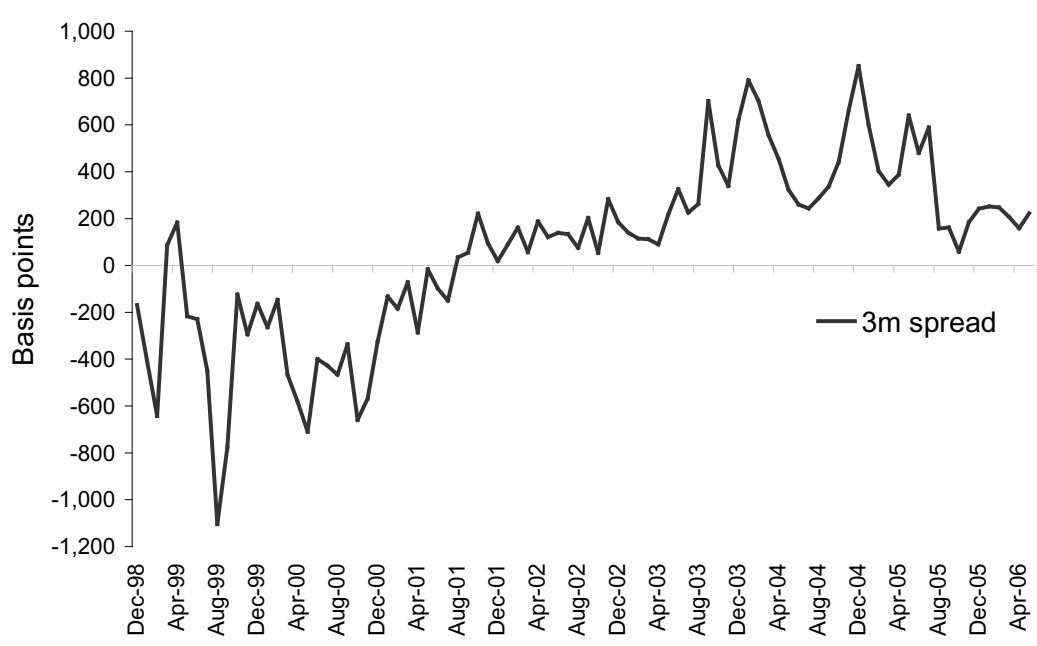

Note: Onshore less offshore yield.

Sources: Bloomberg; PBC; authors' own estimates. 


\section{Onshore-offshore renminbi yield differentials based on PBC bills}

The above finding that offshore renminbi yields have traded consistently below those onshore in the past two years is confirmed by another test based on a newly available and more liquid benchmark money-market yield in renminbi in China. As noted above, the introduction of a weekly auction of PBC bills in early 2004 has provided an alternative basis for comparison of domestic renminbi money-market yields with the renminbi yields implied by the NDFs traded offshore. This more telling and updated test-covering the two and half years between April 2004 and November 2006 — produces a much smoother estimate of the yield gap, consistent with better liquidity in both markets (Figure 14.4).

This more refined and updated test based on trading in liquid market segments offers further evidence of binding controls. From April 2004 to April 2007 , the one-year PBC bill yielded, on average, 250 basis points more than the yield implied by the offshore NDF. This gap of 250 basis points compares with an average of 320 basis points based on the three-month CHIBOR. Both suggest two distinct phases in the yield gaps since April 2004. Before the July 2005 policy move, the gap was wider and more volatile, reacting to policy comments and market rumours. The average spread for this first phase was about 400 basis points on both estimates. After the July 2005 policy shift, the yield gap shrank to 100-200 basis points for three-month CHIBOR and the one-year PBC bill auction yields and stayed there until the gaps widened again into 2007.

\section{Onshore-offshore yield gaps since the July 2005 policy change}

How should this convergence of offshore to onshore renminbi yields in 2005-06 be interpreted? It is remarkable that the onshore-offshore interest differential narrowed sharply in the wake of the July 2005 policy change and remained quite narrow until the end of 2006. Those observers with a prior conviction that capital controls lost effectiveness in the presence of growing cross-border flows might read the reduction of the onshore-offshore renminbi interest rate differential as demonstrating their convictions. This possible interpretation is simple. We offer a more nuanced interpretation that allows scope for policy and temporary opportunities to evade controls.

Regarding policy, we see the initial narrowing of the onshore and offshore renminbi yield differential as a chosen outcome of policy rather than as a forced outcome of the weight of money. In the approach to the depegging, the Chinese authorities doubtless appreciated the risk of a market reaction to any managed exit strategy. In these circumstances, prudence might suggest a policy of not relying too heavily on capital controls, even if these were judged generally effective. As it happened, rising US interest rates offered the option 
Figure 14.4 Onshore less offshore NDF-implied yields, 2004-2007 (in basis points)

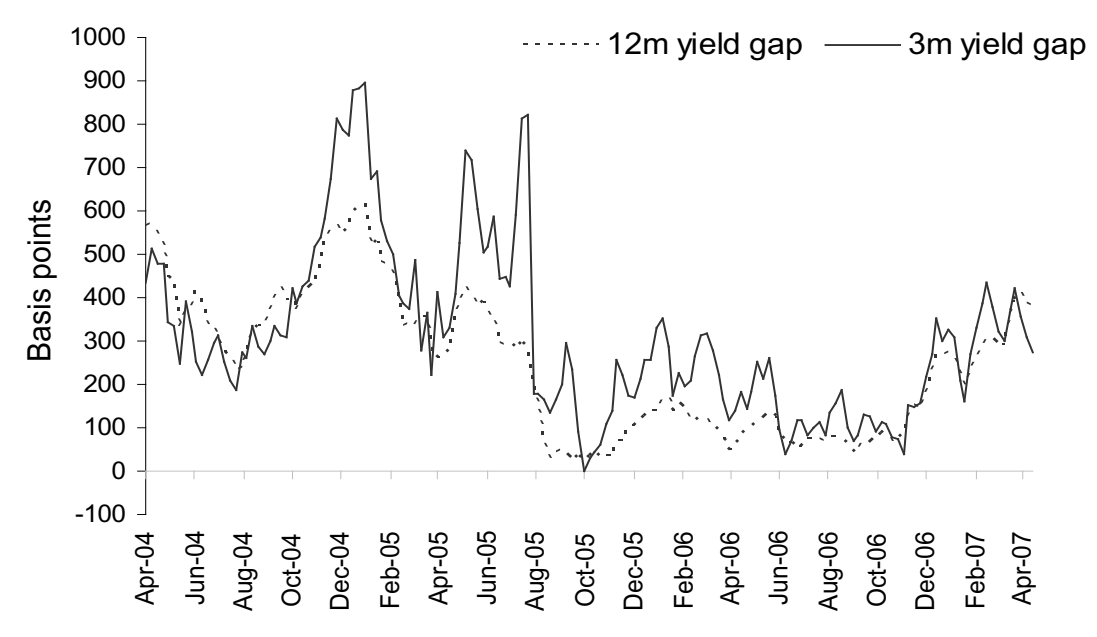

Note: weekly data; 12-month (three-month) NDF, one-year PBC bill yield (three-month CHIBOR) and 12-month (three-month) Libor.

Sources: People's Bank of China; Bloomberg; Bank for International Settlements estimates.

of what might be termed an opportunistic policy of uncovered interest parity. Thus, in the months before and after July 2005, Chinese authorities widened the renminbi-dollar interest gap by reducing the one-year PBC bill rate through policy rate cuts against the backdrop of rising US policy rates. This opened up a 3-4 per cent gap between US dollar and renminbi yields.

Then after July 2005, the Chinese authorities shaped expectations of a 3-4 per cent annual appreciation through statements and the actual pace of the spot crawl. Indeed, market expectations seemed to have been remarkably well contained during the transition ( $\mathrm{Ma}$ and McCauley forthcoming). The consistency of such exchange rate expectations and the dollar-renminbi interest rate differential served to keep onshore and offshore renminbi rates not too far out of line. Our interpretation suggests that the PBC de facto behaved as though interest rate parity were an operating target in setting interest rates and the speed of the crawl, thereby possibly lowering the risks inherent in the regime transition. This approach reduced reliance on the considerable capital controls still in place, albeit to some extent at the cost of relying more on the non-interest rate instruments of monetary policy. 
There were also temporary opportunities to evade the capital controls that arose because of the lag between market development and the articulation of capital controls. In particular, the development in 2006 of an onshore forward market might have added a new channel for inflows that helped to narrow the onshore-offshore differential. An onshore renminbi forward market was first introduced in late 2005. ${ }^{7}$ This onshore forward market allowed some players with a presence in both the onshore and offshore markets to engage in arbitrage. In particular, such players could buy renminbi forward in the onshore market (at relatively high implied interest rates) and simultaneously sell renminbi forward in the offshore market (at relatively low implied interest rates). Much like borrowing renminbi offshore and placing renminbi onshore, such transactions would tend to raise the offshore interest rates towards domestic interest rate levels, bringing the onshore and offshore forward curves closer to each other than otherwise. Such transactions were apparently made possible by a lacuna in the onshore prudential regulation of net foreign currency positions for banks, which set limits on net spot but not forward positions. In effect, the development of the onshore forward market created a temporary channel for arbitrage, though not one wide enough to raise offshore rates to domestic levels.

Our nuanced interpretation is supported by development since early 2007, when the onshore-offshore renminbi yield gaps started widening again to more than 300 basis points, putting capital controls to a stronger test. In our view, this latest widening has less to do with the resurgent efficacy of capital controls than with a partial reversal of the above factors. In response to the inflows related to arbitrage between the offshore and emerging onshore forward markets, Chinese authorities have, since the third quarter of 2006, tightened the rules. Measures taken have included an explicit prohibition of onshore institutions from participating in the offshore NDF market, an inclusion of forward positions in the new prudential regulations of net bank foreign currency positions and a sharp reduction in the de facto ceiling on Chinese residents bringing dollars onshore. ${ }^{8}$ Moreover, since mid 2006, the accelerated pace of spot appreciation and the larger recorded trade surpluses have conditioned market expectations of future appreciation, forcing the implied offshore yields to return to zero or even into negative territory. Since the one-year PBC bill yield rebounded from a low of 1.5 per cent about mid 2005 to 2.8 per cent by late 2006, the onshore-offshore yield gap widened further.

In total, the wide differences between onshore and offshore renminbi interest rates point to the efficacy of capital controls. Most recently, the Chinese authorities guided domestic interest rates and expectations of appreciation into broad consistency with rising US dollar interest rates to reduce the risks inherent in the initial exchange rate regime shift. The resulting one percentage 
point gap between onshore and offshore renminbi yields might have been desired in order to lessen the policy burden on capital controls, which have been binding but not watertight. The experience with the onshore forwards in 2005-06, however, suggests that maintaining effective capital controls gets harder with the development of financial markets and further deregulation of cross-border transactions. The wider yield gaps since early 2007 nevertheless point to a regime of still-binding capital control in China.

\section{Price measures: tests of uncovered interest parity}

The failure of the onshore and offshore renminbi yields to equalise through cross-border arbitrage indicates that capital controls bite. This in turn points to a degree of monetary independence in China. This section addresses this question directly by first assessing the relationship between short-term yields in China and the United States and then by comparing the renminbi-dollar short-term interest rate gap with those of the Hong Kong dollar-US dollar and euro-US dollar pairs.

Interest rate differentials in a period of de facto fixed exchange rates

China and the United States went through very distinct interest rate cycles between 1996 and 2006, despite the de facto dollar peg of the Chinese renminbi until July 2005. Figure 14.5 reveals sizeable and sustained, albeit varying, differentials between short-term renminbi yields in China and the US dollar yields in the United States and the United Kingdom. Yield differentials, whether measured in terms of policy rates or short-term money market rates, have generally been 100 basis points or more in absolute value. In sum, experience between the tightening of the peg to the dollar in 1997 and its loosening in mid 2005 suggested that Chinese monetary authorities could still set a somewhat independent domestic policy (even in the face of capital flows responsive to the resulting yield gap, as shown below).

Cheung et al. (2003) fit autoregressive models to the short-term interest rate differential between China and the United States and find that

...the lagged uncovered interest differential variables are positively significant and indicative of strong persistence...If monies are free to move across markets, arbitrage can generate profits based on the pattern of persistent deviation and help restore the parity. However, this kind of arbitrage activity is quite difficult, especially in the short run, given the prevailing capital controls in the PRC (Cheung et al. 2003:11).

Another finding of Cheung et al. (2003) has been read by Eichengreen (2004) as indicating that the capital controls have become less effective over time. 
In particular, Cheung et al. (2003) report a statistically significant downward trend in the interest rate differential in the sample period from January 1996 to May 2002. ${ }^{9}$ Eichengreen's interpretation is weakened, however, since the result depends on data from the early to mid 1990s. Recall that China experienced a bout of moderately high inflation—reaching 20 per cent-in 1994-95, triggering a draconian tightening by the authorities. The one-month Chinese interbank rate remained at double-digit levels in 1995-97 and remained at 6-8 per cent throughout 1998. Only after the East Asian financial crisis had delivered sharp deflationary shocks to the Chinese economy through its appreciation of the effective exchange rate of the renminbi did Chinese policymakers cut interest rates repeatedly.

We test the following three hypotheses: that the US dollar-renminbi interest rate differential (in absolute terms) is significantly different from zero; that the differential has shown a declining trend; that the average differential or its trend changed during the sample period. Our tests are based on the three measures of interest rates in Figure 14.6 for July 1997 and July 2005 and allow for possible datum breaks within this sample period. Table 14.1 reports the test results, confirming the view that China's capital controls remain effective.

Figure 14.5 Domestic renminbi yields less US dollar yields, 1997-2005 (in basis points)

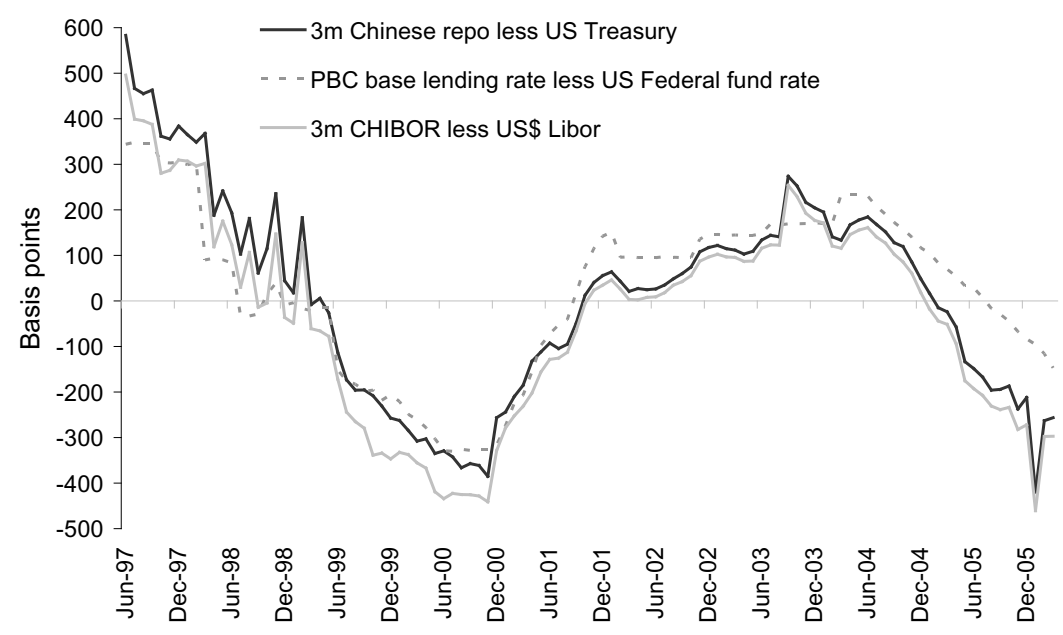

Source: CEIC Data Company. 
First, for the whole sample period from 1997 to 2005, or for subsamples, the absolute values of the dollar-renminbi nominal interest rate differentials differ significantly from zero for all three interest rate measures. Secondly, though it appears from the entire sample period that the differential was trending downwards, the hypothesis of a declining trend in the dollar-renminbi interest rate differentials is rejected within the subsamples.

Finally, when the data are allowed to determine the most likely shift point, the tests reject the null hypothesis of no break. In particular, induction identifies a break in the neighbourhood of mid 2001—roughly the mid point of the sample period. Given this break, the absolute sizes of the interest rate differentials between the renminbi and the US dollar are narrower for the second half of the sample than for the first half, but remain substantial statistically. As noted, however, there is little evidence of a declining trend within the subsamples, and indeed we find the wrong sign for the estimated trend coefficients in all cases.

The econometric evidence in Table 14.1 confirms the hypothesis of significant renminbi-US dollar interest rate differentials. This is a strong statement that, on average, China's capital controls have been effective in maintaining a wedge between interest rates on the US dollar and renminbi, despite the de facto dollar peg of the renminbi. Our statistical tests do not support the hypothesis of a declining trend in the interest rate differentials, once a break in the sample is allowed. In particular, during 2001-05, when China deepened its participation in the global economy considerably and controls were generally relaxed, the estimated trend convergence of short-term interest rates has the wrong sign in all of the cases. If closer financial integration forces interest rate convergence given exchange rate stability, it is hard to account for the lack of convergence in more recent years.

Thus, the distinct interest rate cycles in China and the United States support the idea that China's capital controls have bound sufficiently to provide policymakers some degree of short-term monetary autonomy under a de facto dollar peg. ${ }^{10}$ We interpret the observed convergence of policy rates in the $1990 \mathrm{~s}$ as owing more to inflation convergence than to weaker capital controls. Rather than happenstance, the inflation and interest rate convergence in 1996-2000 can be seen as reflecting the dollar peg's provision of a useful medium-term monetary anchor through prices for traded goods. ${ }^{11}$ What matters for the present analysis, however, is that, in the context of low inflation in both countries, capital controls have permitted Chinese interest rates to diverge from those of the Federal Reserve, notwithstanding the exchange rate linkage. 


\section{Relative monetary independence}

It might be argued that the yield differentials just considered are not wide enough to indicate monetary independence. This objection suggests the usefulness of some benchmarks. How do the differentials between the domestic renminbi yields and US dollar yields compare with those between the Hong Kong dollar and US dollar yields as well as those between the euro and US dollar yields? As a small open economy, Hong Kong has a dollar-based currency board system and no capital controls whatsoever. The euro area, on the other, is a large economy, but one with a flexible exchange rate and an open capital account. The latter is a much more stringent test than a benchmark based on the US dollar-Hong Kong dollar pair. Any similarity in dollar and euro yields cannot

\section{Table 14.1 Renminbi-US dollar interest rate differential}

$\mathrm{Y}=$ differential between the PBC lending rate and US Federal fund rate

(1)

$$
\mathrm{Y}=194.5-0.73 \mathrm{~T}
$$

$\operatorname{Adj}-R^{2}=0.033 ; D W=0.119$

$(4.10)^{* *}(-1.05)$

(2)

$$
\begin{array}{lll}
Y=152.8 D_{1}+106.5 D_{2}+1.57 T_{1}+0.79 T_{2} \\
(1.89)^{*} & (4.28)^{* *} \quad(0.65)(0.66)
\end{array}
$$$$
\text { Adj- } R^{2}=0.11 ; D W=0.145
$$

Wald Tests: $F(2,93)=2.06$

$\mathrm{Y}=$ differential between three-month Chinese repo and three-month US T-bill

$$
\begin{aligned}
& Y=266.0-1.87 \mathrm{~T} \\
& (5.4)^{* *}(-2.82)^{* *}
\end{aligned}
$$

$$
\begin{array}{ll}
Y=186.3 D_{1}+47.9 D_{2}+2.69 T_{1}+1.88 T_{2} \\
(2.39)^{* *} \quad(1.86)^{*} \quad(1.1) \quad(1.89)^{*}
\end{array}
$$

Wald Tests: $F(2,132)=9.48$

$\mathrm{Y}=$ differential between three-month CHIBOR and Libor

$$
\mathrm{Y}=272.0-2.02 \mathrm{~T}
$$$$
(5.83)^{* *}(-2.96)^{* *}
$$

$$
\begin{aligned}
& Y=274.6 D_{1}+64.0 D_{2}-1.35 T_{1}+1.64 T_{2} \\
& (3.75)^{* *} \quad(2.87)^{* *}(-0.6) \quad(1.65)^{*}
\end{aligned}
$$

$\operatorname{Adj}-R^{2}=0.155 ; D W=0.153$

$\operatorname{Adj}-R^{2}=0.218 ; D W=0.258$

$\operatorname{Adj}-R^{2}=0.334 ; D W=0.327$

Wald Tests: $F(2,132)=7.19$

Notes: All dependent variables are expressed in absolute value. $T=$ linear trend; $T_{1}\left(T_{2}\right)=$ linear trend for the first (second) period; $D_{1}\left(D_{2}\right)=$ dummy variable for the first (second) period. Newey-West estimation on the monthly data for July 1997 and July 2005: according to the log likelihood ratios, the most likely breaking points vary but concentrate around May, June and July 2001, so we impose a common break point at June 2001. The Wald Test statistics are for the joint null hypothesis of equal intercepts and slopes. Numbers in parentheses are t-statistics: ** indicates 5 per cent significance; * indicates 10 per cent significance.

Source: Authors' calculations. 
reflect the exchange rate policy of the euro area (unlike, say, any similarity in US dollar and Hong Kong dollar yields).

The Hong Kong dollar-US dollar benchmark highlights the efficacy of capital controls in China, since Hong Kong has complete capital mobility but China has maintained substantial controls, yet both linked their currencies tightly to the US dollar. As expected, the Hong Kong dollar-US dollar yield pairs exhibit much narrower and more stable differentials and much higher correlations than do the CHIBOR-Libor pairs at one-week and three-month maturities (Table 14.2). In particular, the Hibor-Libor correlations are close to unity, compared with less than one-third for the CHIBOR-Libor pairs. This is a classic case of a small open economy choosing a fixed change rate and giving up its monetary autonomy, regardless of the respective business cycles. Hence the Hong Kong dollar-US dollar benchmark is highly advantageous to our argument that China's capital controls have substantially hindered cross-border arbitrage. One drawback of using the Hong Kong dollar-US dollar benchmark, however, is that it can only suggest that China's interest rate setting has more room to manoeuvre than an economy with very little such room.

A more stringent test based on the euro-US dollar benchmark-where there is a strong presumption of autonomy in interest rate setting-still supports our arguments. It is more stringent because, even with other things being equal, the sheer size of the euro area or of China would secure itself greater autonomy relative to Hong Kong. The euro-US dollar yield pairs have narrower and more stable differentials than do the renminbi-US dollar pairs (Table 14.3).

\section{Table 14.2 Interbank rate differentials: renminbi-US dollar and Hong Kong dollar-US dollar (bps)}

\begin{tabular}{lcccc} 
& \multicolumn{2}{c}{ One-week } & \multicolumn{2}{c}{ Three-month } \\
& CHIBOR- & Hibor- & CHIBOR- & Hibor- \\
& Libor & Libor & Libor & Libor \\
Average of absolute difference & 160.5 & 54.1 & 166.6 & 47.0 \\
Maximum of differential & 173.4 & 71.2 & 213.2 & 99.7 \\
Minimum of differential & -429.6 & -222.8 & -439.0 & -213.0 \\
Standard deviation & 181.4 & 54.8 & 194.9 & 58.9 \\
Correlation coefficient & 0.32 & 0.97 & 0.21 & 0.97
\end{tabular}

Note: The interbank market offer rates are CHIBOR for the renminbi, Libor for the US dollar and Hibor for the Hong Kong dollar. Monthly data from January 1999 to March 2006.

Source: CEIC Data Company. 


\section{Table 14.3 Interbank rate differentials: renminbi-US dollar and euro- US dollar (bps)}

\begin{tabular}{lcccc} 
& \multicolumn{2}{c}{ One-week } & \multicolumn{2}{c}{ Three-month } \\
& CHIBOR- & Euribor- & CHIBOR- & Euribor- \\
& Libor & Libor & Libor & Libor \\
Average of absolute difference & 160.47 & 143.45 & 166.64 & 144.56 \\
Maximum of differential & 173.36 & 190.04 & 213.16 & 166.81 \\
Minimum of differential & -429.58 & -281.50 & -439.01 & -284.07 \\
Standard deviation & 181.39 & 156.60 & 194.88 & 157.37 \\
Correlation coefficient & 0.32 & 0.58 & 0.21 & 0.60
\end{tabular}

Note: The interbank market offer rates are CHIBOR for the renminbi, Libor for the US dollar and Euribor for the euro; monthly data from January 1999 to March 2006.

Source: CEIC Data Company.

More tellingly, for the period under consideration, Euribor and Libor exhibit greater positive co-movements than do the CHIBOR and Libor. These results hold as well across split samples. Thus, the evidence from interbank market yields suggests that China-with a fixed exchange rate and continued capital controls-does not import its interest rate policy from the United States to any greater extent than the euro area. This observation is consistent with the view that capital controls in China remain binding.

\section{Conclusion}

The analysis in this chapter finds that China's capital controls remain substantially binding. They prevent the equalisation of onshore renminbi yields and those implied by offshore NDFs. We also find that the observed convergence of short-term interest rates between China and the United States was more characteristic of the mid to late 1990s than of the years since. With its remaining capital controls, China's short-term interest rate setting seems less imported from the United States than either that of Hong Kong (as a small open economy with a hard dollar peg) or that of the euro area (as a large economy with a flexible exchange rate).

The partial convergence of onshore and offshore renminbi yields during mid 2005 and late 2006 is interpreted as reflecting the authorities' choice to act as though they were bound by interest rate parity. That is, in the transition from the pegged regime, the Chinese authorities found it convenient to take 
the burden off the capital controls by signalling a rate of appreciation against the dollar that was broadly consistent with the US dollar-renminbi interest rate differential. We also recognise an element of unintended and temporary relaxation of capital controls resulting from financial market development getting ahead of the controls. The latest onshore-offshore gaps have, however, widened and remain large; and it appears that the authorities are again testing the effectiveness of capital controls.

Over time, financial market development and further lessening of controls should pave the way for phased integration of China into the global market, and will diminish the importance of the remaining controls. Nevertheless, our findings of binding capital controls in China could also help shed light on how policymakers in China will pace the country's continuing capital account liberalisation. Our analysis suggests that the choices regarding liberalisation will affect more than the form of inflows.

\section{Notes}

1 Lane and Milesi-Ferrantti (2006) find that China's stock of international assets and liabilities has barely kept pace with the global stock, in contrast with China's growing share of global GDP and international trade. They compare asset/liability stocks with GDP flows, while we compare two types of international flows. On our measure, China's financial integration is outpacing its trade integration.

2 Gross capital account flows are likely underestimated relative to gross current account flows because some capital flows take the form of current account transactions in order to avoid official restrictions (see below). Also, most reported bank-related gross flows represent changes between two dates and do not capture any intervening gross flows.

3 For related literature on capital mobility and controls, see Frankel (1992) and Otani and Tiwari (1981). Capital controls are also discussed in the contexts of liberalisation sequence (Frankel 2004; Prasad et al. 2005) and financial contagion (Kawai and Takagi 2001). An overview of the Asian NDF markets can be found in Ma et al. (2004) and Debelle et al. (2006). The key inter-bank interest rates used in this chapter are London inter-bank offer rate (Libor) for the US dollar, the Chinese inter-bank offer rate (CHIBOR) for the renminbi and Hong Kong inter-bank offer rate (Hibor) for the Hong Kong dollar.

4 The PBC introduced a new set of benchmark interbank money market reference rates, Shanghai Interbank Offered Rates (SHIBOR), in January 2007.

5 China Money, No. 2, 2006:76.

6 Negative nominal interest rates implied by the pricing of forward exchange rates are not prima facie evidence of an inefficient market. It might be recalled that, during the period of zero yen interest rates, fractionally negative interest rates in yen were implied by yen-dollar swaps. What kept the negative interest rate only fractionally negative was foreign banks parking the yen funds in non-interest-bearing current accounts at the Bank of Japan. The analogy is imperfect because the negative interest rate in yen available to foreign banks reflected the credit standing of the Japanese banks and their need to raise dollars. But the analogy is 
useful in that it highlights the fact that in the Chinese case controls prevented non-residents from obtaining interest-bearing or even non-interest-bearing long positions in the renminbi onshore, so some were willing to pay interest on long forward positions offshore.

7 In the onshore forward and swap market, the forward rates have been priced primarily by differentials between onshore interest rates and US dollar interest rates and made available mainly for hedging for real underlying transactions.

8 A Chinese individual now can bring onshore only a maximum of US $\$ 50,000$ per annum under the current account, down from a previous de facto ceiling of US $\$ 300,000$.

9 The authors caution: '[t]here is a subtlety involved in using parity conditions to evaluate the level of integration. When a parity condition is rejected, then...diminutions of deviations may be due either to greater economic integration, greater convergence of economic policies, or both' (p.6). We incline to policy convergence.

10 Indeed, Granger causality tests suggest that of the three interest rate pairs shown in Figure 14.6 , none of the causality runs from the US rate to the Chinese rate. Indeed, the null hypothesis that the three-month Chinese repo yield does not cause the three-month US Treasury bill yield cannot be rejected. This runs counter to the general view that the United States is a global interest rate setter and China a follower.

11 Robert Mundell and Ron McKinnon have long stressed the importance of the renminbi's de facto dollar peg as a credible nominal anchor. It remains, however, an empirical question as to how much of the inflation convergence should be attributed to this anchor as opposed to strong-arm Chinese macro controls. The US Federal Reserve tightened aggressively from 1994 to mid 1995 when the renminbi was first stabilised against the US dollar. In the next three years, the Federal Reserve eased somewhat while former Chinese Premier Zhu Rongji took forceful measures to control domestic inflation until the East Asian financial crisis delivered strong deflationary shocks to the Chinese economy.

\section{References}

Cheung, Y-W., Chinn, M.D and Fujii, E., 2003. The Chinese economies in global context: the integration process and its determinants, Working Paper No.10047, October, National Bureau of Economic Research, Cambridge, MA.

Debelle, G., Gyntelberg, J. and Plumb, M., 2006. 'Forward currency markets in Asia: lessons from the Australian experience', BIS Quarterly Review, September:53-64.

Eichengreen, B., 2004. Chinese currency controversies, Paper presented at the Asian Economic Panel of Hong Kong, April.

Frankel, J., 1992. 'Measuring international capital mobility: a review', American Economic Review, 82(2):197-202.

- - 2004. On the renminbi: the choice between adjustment under a fixed exchange rate and adjustment under a flexible rate, Paper presented at the High-Level Seminar on Foreign Exchange System, Dalian, 26-27 May.

Kawai, M. and Takagi, S., 2001. Rethinking capital controls (unpublished). 
Lane, P. and Milesi-Ferrantti, G.M., 2006. The external wealth of nations Mark II: revised and extended estimates of foreign assets and liabilities, 1970-2004, Working Paper, No. 06/69, International Monetary Fund, Washington, DC.

Ma, G., Ho, C. and McCauley, R.N., 2004. 'The markets for non-deliverable forwards in Asian currencies', BIS Quarterly Review, June:81-94.

Ma, G. and McCauley, R. (forthcoming). Are China's capital contro/s still binding?, BIS Working Papers, Bank for International Settlements, Basel.

Otani, I. and Tiwari, S., 1981. Capital controls and interest rate parity: the Japanese experience 1978-81, Staff Papers, December, International Monetary Fund, Washington, DC:793-815.

Prasad, E., Rumbaugh, T. and Wang, Q., 2005. Putting the cart before the horse? Capital account liberalization and exchange rate flexibility in China, Policy Discussion Paper, PDP/05/01, International Monetary Fund, Washington, DC.

Prasad, E. and Wei, S.J., 2005. The Chinese approach to capital inflows: patterns and possible explanations, Working Papers, No. 05/07, International Monetary Fund, Washington, DC.

\section{Acknowledgments}

The authors wish to thank participants of the conference China and Emerging Asia: reorganising the global economy, 11-12 May 2006, Seoul; the New Monetary and Exchange-Rate Arrangements for East Asia conference, 22-27 May 2006, at the Bellagio; and a Bank for International Settlements seminar for their comments. Special thanks go to Claudio Borio, George M. von Furstenberg and Yu Yongding. The views expressed are the authors' and not necessarily those of the Bank for International Settlements.

\section{Appendix}

The spread between onshore yields and NDF-implied offshore yields In the absence of capital controls, the forward exchange rate of the home currency is linked by arbitrage to its spot rate and the interest rate differential between the home currency and the dollar through the covered interest parity condition (Ma et al. 2004).

$$
\mathrm{F}=\mathrm{S}(1+\mathrm{r}) /\left(1+r^{\$}\right)
$$

where ' $F$ ' is the forward rate, ' $S$ ' the spot rate, ' $r$ ' the interest rate on the home currency and $r^{\$}$ the dollar interest rate. When there are no cross-border restrictions, borrowing and lending ensure that the above holds. 
When capital controls bind, however, non-residents might not have full access to onshore credit or placements, giving rise to NDFs.

$$
\mathrm{NDF}=\mathrm{S}(1+\mathrm{i}) /\left(1+\mathrm{r}^{\$}\right)
$$

where ' $i$ ' is the NDF-implied yield on the home currency offshore. Note that by definition, ' $i$ ' is not constrained by the zero lower bound and could be substantially negative. To the extent that the arbitrage between the onshore money market and offshore NDF market is effectively constrained by capital controls, the NDF-implied offshore interest rate, ' $i$ ', can differ considerably from the interest rate prevailing in the onshore money market, ' $r$ '. A large and persistent onshore-offshore spread $(r-i)$ indicates the presence of effective cross-border restrictions. The sign of the yield gap could also reveal prevailing market conditions: a positive sign implies appreciation pressures on the home currency in the presence of capital controls and vice versa.

While a persistently big onshore-offshore yield gap indicates market segmentation, a temporarily narrower gap will not necessarily suggest less effective capital controls. One possibility is that market conditions are such that appreciation or depreciation pressures on the currency are largely absent so that the estimated yield gap is relatively small.

Another, in principle equivalent, approach is to estimate the implied onshore yield on the home currency using the onshore deliverable forwards and then to compare it with the NDF-implied offshore yield. Alternatively, one could compare the onshore deliverable forwards directly with their NDF counterparts to derive a forward premium spread. The merits of these different approaches depend in part on data availability and market liquidity. In China's case, these alternative measures could become more useful over time, as the relevant onshore markets develop and data become more available. 
Table A14.1 Credit default swap rates for People's Republic of China and British Bankers Association's Libor panel banks (at the oneyear maturity in 2004-2006, in basis points)

\begin{tabular}{lccc}
\hline & Low & High & Average \\
Issuer & 5.4 & 27.6 & 11.2 \\
People's Republic of China & & & \\
US dollar Libor panel members: & 2.7 & 24.6 & 6.8 \\
Bank of America & 5.0 & 9.0 & 6.9 \\
Barclays & 1.9 & 15.5 & 4.7 \\
Citibank & 1.8 & 9.0 & 4.5 \\
HBOS & 2.2 & 9.8 & 4.2 \\
HSBC & 1.3 & 23.0 & 4.9 \\
JP Morgan Chase & 1.9 & 6.5 & 3.4 \\
Lloyds & 6.8 & 20.0 & 19.0 \\
BMTU & 5.8 & 11.9 & 9.4 \\
Norinchukin & 3.4 & 6.2 & 5.9 \\
Rabobank & 2.7 & 11.4 & 4.0 \\
Royal Bank of Scotland & 2.0 & 7.3 & 5.1 \\
Royal Bank of Canada & 1.9 & 22.8 & 3.5 \\
UBS & 2.8 & 17.1 & 6.9 \\
WEST LB & 3.0 & & 6.4 \\
Average across banks & & & \\
& & & \\
\hline
\end{tabular}

Source: Markit (available online at http://www.markit.com/marketing/index.php). 